\title{
The Professionalism of Vocational High School Supervisors: A Study of Qualitative Analysis
}

\author{
Elfi Tasrif \\ Universitas Negeri Padang, Indonesia \\ *Corresponding author, e-mail: elfitasrif@ft.unp.ac.id
}

\begin{abstract}
Supervisors carry out educational supervision to develop a better-quality learning environment, including vocational high schools (VHS). This research is qualitative research with a case study research design. The main target of the research is VHS supervisors in Padang City. This research is limited to describing the professionalism of supervisors qualitatively. The data sources of this research were crucial informants, who were determined purposively. Data collection techniques with interview and observation techniques. Data analysis by collecting data, coding, linking, and interpreting themes. The results showed that the professionalism of VHS supervisors in carrying out their duties is still not following the quality standards of supervisors. The conclusion is that the supervisor's low professionalism is indicated by the supervisor's low motivation, lack of pride in his profession as a supervisor, the supervisor is not independent, and the supervisor's verbal communication is not good.
\end{abstract}

Keywords: Professionalism, Vocational High School, Supervisor.

How to Cite: Tasrif, E. (2021). The Professionalism of Vocational High School Supervisors: A Study of Qualitative Analysis. International Journal of Research in Counseling and Education, 5 (1): pp. 7-14, DOI: https://doi.org/10.24036/00408za0002

\section{Introduction}

Vocational High School (VHS) is a secondary education that prepares students especially to work in certain fields. VHS graduates are prepared for three things, namely: 1) VHS graduates are prepared to be able to work in the business and industrial fields. 2) VHS graduates are prepared to be able to continue their education to the next level through vocational education in order to increase expertise in certain fields. 3) VHS graduates are prepared for entrepreneurship (Hidayat, 2017a; Yulastri, \& Hidayat, 2017; Yulastri et al., 2018; Hidayat et al., 2018; Hidayat \& Yuliana, 2018; Hidayat et al., 2019a). Preparing students to meet targets after graduation, namely Work, Continuing Education, and Entrepreneurship is the responsibility of all variables including curriculum, educators, and educational institutions (Yulastri et al., 2019; Hidayat et al., 2019b; Ganefri et al. , 2020; Hidayat et al., 2020). VHS graduates are also prepared to have employability skills as a person's ability to actively adapt to a job. Vocational high schools as potential workers must provide a good education system, have good school governance, and other supporters to improve student competencies so that graduates have bargaining power (Hidayat, 2015). If this happens, the industry as a labor absorber will open up greater opportunities for employment of VHS graduates, because in principle the industry has qualified human resources. However, in fact, based on data from the Central Statistics Agency (BPS) as of February 2021, the graduates of Vocational High School (VHS) are still the highest compared to graduates of other education levels, namely 11.45 percent. This is very unfortunate considering that VHS graduates are prepared to be ready to work and become entrepreneurs, but empirical data shows the opposite, namely that most VHS graduates are unemployed. These constraints and problems, cannot be separated from the management and governance mechanisms of vocational high schools (Suchyadi et al., 2019; Suharsongko, 2019; Rohendi, 2020; Tasrif et al., 2021), including the educational supervision activities carried out by supervisors in VHS (Tasrif, 2019).

Teachers in VHS have an important role in determining the quality and success of a school's education (Ganefri et al., 2017). In addition, research finds that vocational teachers who teach effectively have an impact on student achievement (Hidayat, 2017b). Therefore, efforts are needed to ensure the quality of these 
vocational teachers, and education supervision provides a function to guarantee the quality of learning, including the quality of vocational teachers (Ganefri et al., 2018). Education supervision seeks to ensure and develop teacher quality and performance (Prasetyono, Abdillah, \& Fitria, 2018). Educational supervision aims to develop and improve the quality of education which will also contribute to better student achievement (Yang et al., 2018). Supervision is a process as long as teachers are still careers in the world of education (Aini, 2019) and plays an important role in improving the learning process by fostering schools (Amiruddin, 2018; Brown et al., 2020), including teachers (Ayubi et al., 2020). The term supervision itself is equated with supervision, inspection (Chudzaifah, 2019).

Judging from the object of supervision (Kristiawan et al., 2019), there are three types of educational supervision, namely (1) academic supervision, which is directly related to learning activities and functions to improve and improve the quality of teaching, (2) administrative supervision carried out on administration which supports learning activities, and (3) institutional or institutional supervision, with a broader scope of schools, including curriculum, personnel or employment, school administration or administration, infrastructure, school public relations, and other collaborations for school development (Suharto, 2018; Graham, \& Edwards, 2018). As part of education supervision, academic supervision strives for selfdevelopment and improvement of teacher quality which ultimately aims to improve the quality of education (Susilo, \& Sutoyo, 2019; Djuhartono et al., 2021). Supervision does not aim to simply evaluate and look for deficiencies or mistakes of teachers, but rather to guide them and develop the teaching process that is their job (Eissa et al., 2020). There are several academic supervision techniques, both individual in nature, such as class visits, class observations, individual conversations or meetings, self-evaluation, clinical or group supervision, including orientation meetings, teacher meetings, study or group discussions between teachers, workshops or seminars, inter-school visits or comparative studies, supervision bulletin and learning resource centers (Haris et al., 2019).

Educational supervision and academic supervision are carried out at all levels of education in Indonesia, including at VHS (Hanafy, Nursanga, \& Hasbi, 2019). There is increasing interest and attention to the importance of VHS itself in Indonesia. The higher the participation of Indonesian people in VHS, even though there are differences in the level of participation of parents from different economic backgrounds (Hasan, Juandi, \& Khoiriyah, 2018). VHS in Indonesia tries to face challenges to children's development in the domain of technology, cognitive skills, emotional maturity, communication as well as general knowledge. Supervision activities, both broadly on educational and specific services carried out on employees, including teachers, are planned and carried out routinely at VHS (Hasanah, \& Kristiawan, 2019; Huang et al., 2020). Going well or not depends on the quality and professionalism of supervisors in carrying out supervision activities (Istianah, 2019; Istiqomah, Ekosiswoyo, \& Pramono, 2019). In addition, alarming data can be observed from the research of the Directorate of Education Personnel (2009), which was conducted in six districts/cities in Indonesia, namely Maros Regency, Makassar City, Probolinggo Regency, Surabaya City, Tanah Datar Regency, and Padang City. The results showed that the average attendance of school supervisors was only 30 minutes to one hour.

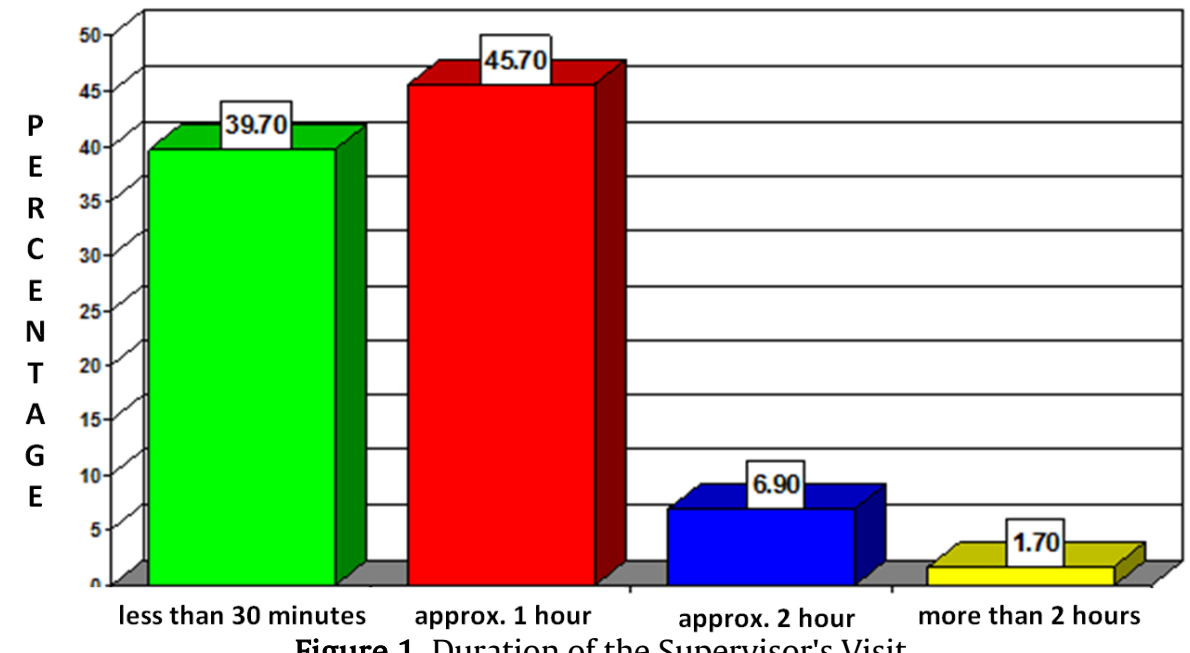

Figure 1. Duration of the Supervisor's Visit

Source: Directorate of Education Personnel (2009)

Such a short visit time is a clear indication of the inadequacy of the supervisory process, in other words, the supervisor only functions as an observer, not a supervisor. The supervisory process that is not optimal at the same time shows that the professionalism of supervisors is very bad. This apprehensive condition based 
on the results of the Directorate of Manpower's research also shows the weakness of coordination between supervisors and school principals, resulting in suboptimal supervision. The unprofessionalism of school supervisors in optimizing their role in schools can be caused by a number of factors (Karyati, 2018; Lalupanda, 2019). So that with this condition it is very necessary to know and carry out an analysis of the professionalism of supervisors, especially in Vocational High Schools.

\section{Method}

This research is qualitative research design in the form of case study research (Selamet, 2017). The main target of the research is the supervisors of VHS in the Padang City by carefully investigating the program of supervision or supervision they carry out, supervision activities, and the supervision process, where the results will be described in a qualitative descriptive form. This study is limited to describing qualitatively the professionalism of Vocational High School Supervisors in the Padang City. The data sources of this research consisted of primary sources, namely sources that directly provided data to data collectors and primary sources obtained through document tracking. The main primary source is obtained through the main source or key informant, namely two vocational school supervisors (P1 and P2). In addition, to enrich information and to cross-check or triangulate data, two stakeholders from the elements of teachers and school principals (S1 and S2) were used. Determination of the sources was done purposively. Data collection techniques using interview and observation techniques. Furthermore, data analysis was carried out by collecting data. Data collection was carried out by researchers as a key instrument by going directly to the field. Doing data coding, namely, the code used in the form of a combination of letters and numbers, for example, WMD1P1 where W = interview, $\mathrm{MD}=$ Informant code (in this study there were four informants, namely MD, MJ, DM, and FZ), P = Supervisor, $\mathrm{S}=$ Stakeholder, while the numeric code (1, 2, 3 and so on) shows 'the process to .....Then the next stage of data analysis is connecting the themes and interpreting the themes.

\section{Results and Discussion}

The results of research from the professionalism of Vocational School Supervisors in the Padang City were obtained from the results of interviews, the results of participant observation, and the results of document studies.

\section{Results of Interview}

The results of interviews with informants related to the professionalism of VHS supervisors can be seen from what is disclosed by the following P1,

(Currently, many school principals have expired their term of office, or may still be in office, but for some reason or another, they have been transferred to become supervisors. This shows that a person to become a supervisor is not due to personal desires or even dislikes this profession, but because of other interests, even though the person concerned actually still wants the position of principal of the school. As a result, the supervisor is not serious in carrying out his supervisory duties and is difficult to be moved-WMD2P1).

Perception P1 reveals doubts about supervisors' attitudes, in particular with regard to their commitment and motivation. This doubt is related to their existence as supervisors because there is an element of their unwillingness to be appointed as supervisors so that when they are given their duties they cannot do it optimally. When P1's perception is cross-checked with P2's perception, it turns out that the meaning expressed by P2 can be said to be the same as what P1 says. In full, the following P2 expression can be seen,

(Work ethic is important ... but in practice it is nil ... as an educated person, I am often disappointed because from a long time ago, the importance of improving quality is the essence of education. Basically, quality improvement is something that is easy to do, as long as carried out together ... in its implementation the discourse of improving quality is only limited to a hollow slogan because what happens is that what is said or planned is out of sync with what is being done, because what is impressed as a waste of funds project. Tiring work but not optimal results-WMJ2P2)

Work ethic or literally stated as work spirit is one of the pillars of being a professional, but it is precisely this work ethic that is the weakness of school supervisors. What P2 says when juxtaposed with the characteristics of professional school supervisors as stated in the School Supervisory Workbook, it can be stated that what Vocational School supervisors in the Padang City have done so far are still not professional because they do not have a good work ethic. 
Further triangulation of sources carried out on S1, can be underlined by the previous S1 statement which stated that "... the supervisor to the school just visited, looked around then filled in the data that he had visited the school ... then just left .. and they are 'outcasts' in their respective schools ..." (WDMS1). Likewise, if the perception of S2, S2 states, "... the existing supervisors consist of people who are less 'valid', who are not productive, former staff, teachers who don't come in ... it's just that they have connections" (WFZS2), although this statement seems sarcastic, all sources agree on the perception that is not in favor of the supervisor.

Many indicators can be marked from a person whether he is professional or not. Some of these indications can be seen, for example, from the inability of supervisors to get rid of dependence on other parties to improve their abilities, they are just waiting for training opportunities from the education office or other agencies to hone their skills, this is an indication that they are less independent. Another indication can also be seen from what is explained by $\mathrm{P} 1$, that the person concerned also often guides or mentors' teachers in teaching subjects that are not in the field of supervisors concerned, how can a professional evaluate people who are not in his/her field. Quite sad data was obtained from P1 and strengthened by S2, namely about the existence of school supervisors who had a frontal fight with the teacher, this happened because the teacher could not accept and always felt blamed by the supervisor. This incident once again shows that the supervisor of the school is still not professional, because emotional control and how to communicate is an indicator of professionalism.

\section{Results of Participant Observation}

Observations made regarding the professionalism of school supervisors were carried out in the form of passive participation, in this case, the researcher looked directly at what was happening without getting involved in activities carried out by supervisors or stakeholders. Observations were made on P1 and P2 as well as other VHS supervisors randomly. Only one or two supervisors came to the school with a little provision, for example, several instruments, even those related to the fields that the supervisor himself had to complete. In other words, the provisions that are brought are part of the obligations that must be fulfilled by the supervisor concerned, such as teacher performance appraisal forms, or other assessment formats.

\section{Results of Document Study}

The document track records that can be observed related to the professionalism of VHS supervisors are generally obtained in the form of activity data collected in the supervisor's bio. In addition, data related to supervisory reports and a number of supervisory instrument documents were also obtained. However, the most basic part as a reference for professionalism is a planned and written work program, starting from the beginning of the year/semester, and this part is not found. If it is found, it is only a fragment of the program, not an integrated program. The supervisory program is just a scribble that is adjusted in such a way when writing a report.

\section{Discussion on the Professionalism of Vocational School Supervisors}

Based on the results of the study, it shows that the professionalism of Vocational School supervisors has not met expectations, especially in improving the quality of academic supervision (Mudjiono, 2018; Pamudji, 2019; Marsellina, 2020). Obtaining data shows signs that are not very encouraging, several things that have emerged are (1) Low motivation of supervisors; (2) Absence of professional pride; (3) Acting not in accordance with the main tasks and functions; (4) Supervisors are less independent; (5) Serving outside the area of expertise; (6) limited academic ability; (7) low innovation; (8) Undertaking unplanned coaching; (9) Poor verbal communication; (10) Low work ethic; (11) Arrogant.

The existence of supervisors in the world of education has a solid foundation and is stipulated by a number of Government Regulations and Ministerial Regulations (Marsalin, 2019). As professional school supervisors, they are assigned to carry out academic and managerial supervision activities as well as mentoring and professional training activities for teachers (Maryam, 2018; Messi et al., 2018; Morrison, \& Lent, 2018; Pitkänen et al., 2018). Based on the School Supervisory Workbook, there are four main tasks of supervision that professional supervisors must have, (1) carefully observing school conditions, (2) analytical acuity and synthesis, (3) accuracy and creativity in providing the necessary treatment, (4) ability good communication with each individual in the school.

Furthermore, the School Supervisors Workbook describes what characteristics these professional school supervisors must possess, including displaying abilities in the form of performance; have talents, interests, vocation, and idealism; carry out supervisory duties effectively and efficiently; provide excellent service to all stakeholders; have a commitment to improving the quality of education; developing supervisory work methods and strategies continuously; have the capacity to work independently; have professional 
responsibilities; comply with the professional code of ethics; have a commitment and become a member of the school supervisory professional organization.

Observing the results of the study, that the professionalism of vocational school supervisors when this research was conducted, has not met the expected standards (Putri, Burhanuddin, \& Wiyono, 2021). Professionalism is not something that is easy to achieve, because professionalism requires the quality and loyalty of professional stakeholders to their profession, in this case, of course, how professional the supervisor is with their work. Rossiter (2008) states, a professional has an attitude that is always capable and can make changes, an innovator, and also a skilled executor. Some of the other characteristics of professionalism are having values and ethics (Carr, 2000), independent, knowledgeable, responsible (Robson, 2006), able to control emotions (Lee, \& Yin, 2011), expert, think analyst, competent in determining attitudes (Allen, \& Velden, 2011), and a number of other indicators from many other experts. If the results of this study are juxtaposed with what is stated by the experts, it will further reinforce the belief that the current Vocational School supervisors are not yet professional. Thus, it becomes naive to talk about improving the quality of academic supervision by unprofessional school supervisors. Professionalism is not enough only with broad skills and knowledge, but professionalism is more about totality in attitude, working smart, working thoroughly, and working seriously in various dimensions.

The results of research related to the professionalism of vocational school supervisors are still far from expectations as professional figures. This situation is inversely proportional to what is expected in research by Bessong and Ojong (2009), that in order to improve teaching, a supervisor is needed, because a supervisor or supervisor is a person who is considered to have competence in knowledge, commitment, and is wise enough to feel 'whatever is desired/questioned 'by the teacher. Besides that, the supervisor is able to provide suggestions and various appropriate solutions, and also the supervisor has the capability to evaluate the progress of the teaching program and the corrections that must be made in order to improve and improve the quality of teaching. All of the criteria put forward by Bessong and Ojong (2009) are characteristics of a person's professionalism. However, in this case, the opposite is the case, the supervisor is not strengthening the education process to make it better quality, but rather the part that must be upgraded.

\section{Conclusion}

The professionalism of Vocational High Schools supervisors in carrying out their duties is not in accordance with the reference in the Supervisory Quality Standard Book as required in the Supervisory Workbook and the Regulation of the Minister of State for Administrative Reform and Bureaucratic Reform concerning the Functional Position of School Supervisors and their Credit Score which this Ministerial Regulation is a revision of the Regulation State Minister for Administrative Reform and Bureaucratic Reform concerning Functional Position of School Supervisors and Credit Score. The low professionalism of the supervisor is indicated by the low motivation of the supervisor, the absence of pride in his profession as a supervisor, the supervisor is not independent, does unplanned coaching even outside his area of expertise, and the supervisor's verbal communication with the teacher is not good.

\section{References}

Aini, N. (2019). Implementasi Supervisi Kepala Sekolah Terhadap Guru di Sekolah Menengah Kejuruan Farmasi Samarinda. Tarbiyah Wa Ta'lim: Jurnal Penelitian Pendidikan dan Pembelajaran, 6(3), 170178.

Allen, J., \& Velden, R. (2011). (Eds). The flexible professional in the knowledge society-new challenges for higher education. London: Springer.

Amiruddin, A. (2018). Urgensi Pengembangan Supervisi Elektronik Berbasis Website Bagi Pengawas Pendidikan Agama Islam di Lingkungan Kementerian Agama Kabupaten Sumenep.Jurnal Kariman, 6(2), 171-182.

Ayubi, U. Y., Syahmuntaqy, M. T., \& Prayoga, A. (2020). Implementasi Supervisi Akademik Kepala Sekolah dalam Meningkatkan Kinerja Pendidik. MANAZHIM, 2(2), 118-130.

Bessong, F. E., \& Ojong, F. (2009). Supervision as an instrument of teaching -learning effectiveness: challenge for the nigerian practice. Global Journal Of Educational Research, 8(1-2), 15-20 .

Brown, J., Reid, H., Dornan, T., \& Nestel, D. (2020). Becoming a clinician: Trainee identity formation within the general practice supervisory relationship. Medical education, 54(11), 993-1005.

Carr, D. (2000). Professionalism and ethics in teaching. New York. Routledge.

Chudzaifah, I. (2019). Supervisi Pendidikan Islam: Telaah Model Pengawasan Madrasah di Kota Sorong. $A L-$ FIKR: Jurnal Pendidikan Islam, 5(2), 18-30. 
Djuhartono, T., Ulfiah, U., Hanafiah, H., \& Rostini, D. (2021). Supervisi Akademik Kepala Sekolah Dalam Meningkatkan Kinerja Guru Kejuruan. Research and Development Journal of Education, 71), 101-115.

Eissa, G., Lester, S. W., \& Gupta, R. (2020). Interpersonal deviance and abusive supervision: The mediating role of supervisor negative emotions and the moderating role of subordinate organizational citizenship behavior. Journal of Business Ethics, 166(3), 577-594.

Ganefri, Hidayat, H., Kusumaningrum, I., \& Mardin, A. (2017). Needs Analysis of Entrepreneurship Pedagogy of Technology and Vocational Education with Production Based Learning Approach in Higher Education. International Journal of Advanced Science, Engineering and Information Technology, 7, 1701-1707. http://dx.doi.org/10.18517/ijaseit.7.5.1510

Ganefri, G., Hidayat, H., Yulastri, A., Mardin, A., Sriwahyuni, D., \& Zoni, A. A. (2018). Perangkat Pembelajaran Pedagogi Entrepreneurship Dengan Pendekatan Pembelajaran Berbasis Produk di Pendidikan Vokasi. In Prosiding Seminar Nasional \& Internasional, 1(1).

Ganefri, G., Hidayat, H., Yulastri, A., \& Ifdil, I. (2020). Need analysis of the production based entrepreneurship training model: learning entrepreneurship in higher education. COUNS-EDU: The International Journal of Counseling and Education, 5(2), 58-63.

Graham, C. M., \& Edwards, M. C. (2018). Supervision of school-based, agricultural education: A historical review. Journal of Research in Technical Careers, 2(1), 42.

Gurková, E., \& Zeleníková, R. (2018). Nursing students' perceived stress, coping strategies, health and supervisory approaches in clinical practice: A Slovak and Czech perspective. Nurse education today, 65, 4-10.

Hanafy, S., Nursanga, N., \& Hasbi, H. (2019). Pengaruh Supervisi Pendidikan Dan Musyawarah Guru Mata Pelajaran Melalui Kompetensi Guru Dalam Meningkatkan Profesionalisme Guru Sekolah Menengah Kejuruan Di Kabupaten Takalar. YUME: Journal of Management, 2(3).

Haris, I., Naway, F., Pulukadang, W. T., Takeshita, H., \& Ancho, I. V. (2018). School Supervision Practices in the Indonesian Education System; Perspectives and Challenges.Journal of Social Studies Education Research, 9(2), 366-387.

Hasan, F., Juandi, W., \& Khoiriyah, U. (2018). Pengembangan Modul Supervisi Bagi Pengawas SMK Kabupaten Situbondo. Jurnal Pendidikan Islam Indonesia, 2(2), 207-220.

Hasanah, M. L., \& Kristiawan, M. (2019). Supervisi Akademik dan Bagaimana Kinerja Guru. Tadbir: Jurnal Studi Manajemen Pendidikan, 3(2), 97-112.

Hidayat, H. (2015). Production based Learning: An Instructional Design Model in the context of vocational education and training (VET). Procedia-Social and Behavioral Sciences, 204, 206-211.

Hidayat, H. (2017a). How is the Application and Design of a Product-Based Entrepreneurship Learning Tools in Vocational Higher Education?. In International Conference on Technology and Vocational Teachers (ICTVT 2017)(pp. 223-228). Atlantis Press.

Hidayat, H. (2017b). Impact of learning with the production-based learning model in vocational school. International Journal of Research in Engineering and Social Sciences, 72), 1-6.

Hidayat, H., Herawati, S., Syahmaidi, E., Hidayati, A., \& Ardi, Z. (2018). Designing of technopreneurship scientific learning framework in vocational-based higher education in Indonesia. International Journal of Engineering and Technology (UAE), 74 ), 123-127.

Hidayat, H., \& Yuliana. (2018). The Influence of Entrepreneurship Education and Family Background on Students' Entrepreneurial Interest in Nutritious Traditional Food Start Ups in Indonesia. International Journal of Engineering and Technology(UAE). 74 ), 118-122. https://doi.org/10.14419/ijet.v7i4.9.20631

Hidayat, H., Tamin, B. Y., Herawati, S., Khairul, K., \& Syahmaidi, E. (2019a). The contribution of technopreneurship scientific learning and learning readiness towards the entrepreneurship learning outcomes in higher vocational education. Jurnal Pendidikan Vokasi, 9(1), 21-32.

Hidayat, H., Ardi, Z., Yuliana, \& Herawati, S. (2019b ). Exploration of the need analysis for technopreneurship scientific learning models in higher vocational education. International Journal of Economics and Business Research, 18(3), 356-368.

Hidayat, H., Tamin, B. Y., Herawati, S., Ardi, Z., \& Muji, A. P. (2020). The Contribution of Internal Locus of Control and Self-Concept to Career Maturity in Engineering Education. Int. J. Adv. Sci. Eng. Inf. Technol, 1066), 2282-2289.

Huang, C. M., Liao, J. Y., Hsu, H. P., Lin, C. Y., \& Guo, J. L. (2020). Perspectives emerged from students and supervisory staff interaction in drug use prevention: AQ methodology investigation. International journal of environmental research and public health, 1715), 5621.

Istianah, I. (2019). Implementasi Program Supervisi Akademik Kepala Sekolah Dalam Meningkatkan Profesionalisme Guru di SMAN 1 Cikarang Utara dan MAN Kabupaten Bekasi.Jurnal Administrasi Pendidikan, 26(1), 72-87.

Istiqomah, D. N., Ekosiswoyo, R., \& Pramono, S. E. (2019). Influence of School Culture, Headmaster Supervision and Interpersonal Communication Towards Teacher's Social Behavior. Educational Management, 8(1), 8-16. 
Karyati, Y. (2018). Keefektifan Supervisi Akademik Kepala Sekolah Dalam Upaya Peningkatan Kualitas Pembelajaran di SMK. Jurnal Media Manajemen Pendidikan, 1(2).

Lalupanda, E. M. (2019). Implementasi supervisi akademik untuk meningkatkan mutu guru. Jurnal Akuntabilitas Manajemen Pendidikan, 71$), 62-72$.

Lee, J.C.K \& Yin, H.B. (2011). New Understandings of Teacher's Work. Day, C. \& Lee, J.C-K. (eds). Emotions and educational change teachers' emotions in a mandated curriculum reform: a chinese perspective. London: Springer.

Kristiawan, M., Yuniarsih, Y., Fitria, H., \& Refika, N. (2019). Supervisi pendidikan. Bandung: Alfabeta.

Mudjiono, M. (2018). Peningkatan Kemampuan Profesional Guru Melalui Supervisi Akademik Teknik Individual Conference (IC) Oleh Pengawas Sekolah Di SMK Kosgoro 2 Ngantang Kabupaten Malang. Jurnal Revolusi Pendidikan (JUREVDIK), 1(2), 57-64.

Marsalin, M. (2019). Pelaksanaan Supervisi Akademik Pengawas Sekolah Sebagai Upaya Peningkatan Profesionalisme Guru di SDN ANTARA. Jurnal Sains Riset, 8(2), 63-70.

Marsellina, R. (2020). Persepsi Guru Tentang Proses Pelaksanaan Supervisi Pembelajaran oleh Kepala Sekolah Menengah Kejuruan Negeri Kelompok Bisnis Manajemen di Kota Padang. Jurnal Bahana Manajemen Pendidikan, 2(1), 620-630.

Maryam, M. (2018). Meningkatkan Kompetensi Guru Melalui Supervisi Akademik yang Dilaksanakan Secara Terpadu Oleh Pengawas Mata Pelajaran di Kabupaten Mamuju Provinsi Sulawesi Barat. Jurnal IImiah Maju, 1(2), 15-23.

Messi, M., Sari, W. A., \& Murniyati, M. (2018). Pelaksanaan supervisi akademik pengawas sekolah sebagai upaya peningkatan profesionalisme guru. JMKSP (Jurnal Manajemen, Kepemimpinan, dan Supervisi Pendidikan), 3(1), 114-125.

Morrison, M. A., \& Lent, R. W. (2018). The working alliance, beliefs about the supervisor, and counseling selfefficacy: Applying the relational efficacy model to counselor supervision. Journal of Counseling Psychology, 65(4), 512.

Pamudji, P. (2019). Peningkatan Kemampuan Profesional Guru Melalui Supervisi Teknik Diskusi Refleksi Kasus (DRK) Oleh Pengawas Sekolah Di SMK Nasional Baureno Kabupaten Bojonegoro. Jurnal Revolusi Pendidikan (JUREVDIK), 2(1), 65-75.

Pitkänen, S., Kääriäinen, M., Oikarainen, A., Tuomikoski, A. M., Elo, S., Ruotsalainen, H., ... \& Mikkonen, K. (2018). Healthcare students' evaluation of the clinical learning environment and supervision-a crosssectional study. Nurse education today, 62, 143-149.

Prasetyono, H., Abdillah, A., \& Fitria, D. (2018). Academic supervision toward teacher's performance through motivation as intervening variable. Journal of Education and Learning (EduLearn), 12(2), 188-197.

Putri, D. C., Burhanuddin, B., \& Wiyono, B. B. (2021). Supervisi Kepala Sekolah Dan Hubungannya Dengan Penguasaan Kompetensi Guru SMK. JAMP: Jurnal Administrasi dan Manajemen Pendidikan, 4(1), 1723.

Robson. J. ( 2006). Teacher professionalism in further and higher education. New York. Routledge- Taylor \& Francis Inc.

Rohendi, A. (2020). Pengaruh Efektivitas Kepemimpinan Kepala Sekolah dan Supervisi Pengawas Terhadap Kinerja Sekolah Pada Sekolah Menengah Kejuruan di Kabupaten Ciamis. Jurnal IImiah Wahana Pendidikan, 6(2), 185-195.

Rossiter, A. (2008). Professional excellence-beyond technical competence. New Jersey. John Wiley \& Sons, Inc.

Selamet, M. (2017). Pengaruh Kompetensi Supervisi Manajerial Dan Supervisi Akademik Pengawas Sekolah Terhadap Kinerja Guru (Studi Deskriptif Kuantitatif pada SMP Negeri di Kota Banjar). Administrasi Pendidikan: Jurnal IImiah Mahasiswa Pascasarjana, 2(1), 73-86.

Suchyadi, Y., Karmila, N., Nurlela, N., Mirawati, M., Handayani, R., Purnamasari, R., ... \& Anwar, W. S. (2019). Increasing Personality Competence Of Primary School Teachers, Through Education Supervision Activities In Bogor City. JCE: Journal of Community Engagement, 1(01), 20-23.

Suharsongko, M. E. (2019). Perkembangan Supervisi Pendidikan. Jurnal Alasma: Media Informasi dan Komunikasi Ilmiah, 1(1), 1-24.

Suharto, S. (2018). Pengaruh Supervisi Akademik Kepala Sekolah dan Lingkungan Kerja Terhadap Kinerja Guru Matematika Sekolah Menengah Kejuruan (SMK) Di Kota Bengkulu.Jurnal Pendidikan Matematika Raflesia, 3(2), 148-155.

Susilo, S., \& Sutoyo, S. (2019). Pengaruh Supervisi Akademik Kepala Sekolah Terhadap Kinerja Guru. JMKSP (Jurnal Manajemen, Kepemimpinan, dan Supervisi Pendidikan), 4(2), 188-193.

Tasrif, E. (2019). Academic Supervision Mechanism by Vocational High School Supervisor. In 5th UPI International Conference on Technical and Vocational Education and Training (ICTVET 2018)(pp. 160164). Atlantis Press.

Tasrif, E., Saputra, H. K., Kurniadi, D., Hidayat, H., \& Mubai, A. (2021). Designing Website-Based Scholarship Management Application for Teaching of Analytical Hierarchy Process (AHP) in Decision Support Systems (DSS) Subjects. International Journal of Interactive Mobile Technologies, 16(9). 
Yang, F., Liu, J., Huang, X., Qian, J., Wang, T., Wang, Z., \& Yu, H. (2018). How supervisory support for career development relates to subordinate work engagement and career outcomes: The moderating role of task proficiency. Human Resource Management Journal, 28(3), 496-509.

Yulastri, A., \& Hidayat, H. (2017). Developing an Entrepreneurship Module by Using Product-Based Learning Approach in Vocational Education. International Journal of Environmental and Science Education, 12(5), 1097-1109.

Yulastri, A., Hidayat, H., Ganefri, G., Edya, F., \& Islami, S. (2018). Learning outcomes with the application of product based entrepreneurship module in vocational higher education. Jurnal Pendidikan Vokasi, $8(2), 120-131$.

Yulastri, A., Hidayat, H., Ganefri, Ayu, R., \& Ardi, Z. (2019). An Empirical Study on The Effects of Pedagogy Learning Tools Entrepreneurship With Product-Based Learning Approach, Learning Readiness, and Locus of Control: A Case From Engineering Education in Indonesia. International Journal of Scientific \& Technology Research, 8(9), 1722-1727. 